DOI:10.17951/h.2019.53.4.53-68

\begin{tabular}{lcc}
\hline & A N N A L E S \\
UNIVERSITATIS MARIAE CURIE-SKŁODOWSKA \\
LUBLIN - POLONIA \\
SOL. LIII, 4 & SECTIO H \\
\hline
\end{tabular}

\author{
JERZY GAJDKA \\ jerzy.gajdka@uni.lodz.pl \\ University of Lodz. Faculty of Economics and Sociology \\ 3/5 Polskiej Organizacji Wojskowej St, 90-255 Łódź \\ ORCID ID: https://orcid.org/0000-0003-1870-3129 \\ MAREK SZYMAŃSKI \\ marek.szymanski@uni.lodz.pl \\ University of Lodz. Faculty of Economics and Sociology \\ 3/5 Polskiej Organizacji Wojskowej St, 90-255 Łódź \\ ORCID ID: https://orcid.org/0000-0001-5762-4840
}

\title{
Changes in the Capital Structure of Polish Companies During the Last Twenty Years (1997-2017)
}

Keywords: capital structure; debt; corporate finance; pecking order theory; trade-off theory

JEL: G32; G38; N24

How to quote this paper: Gajdka, J., \& Szymański, M. (2019). Changes in the Capital Structure of Polish Companies During the Last Twenty Years (1997-2017). Annales Universitatis Mariae Curie-Skłodowska, sectio H-Oeconomia, Vol. 53, No. 4.

\footnotetext{
Abstract

Theoretical background: The capital structure is one of the most important areas in the modern theory of corporate finance. It has inspired the development of a large number of theoretical approaches, but a universally accepted theory of capital structure has not yet been developed. A common belief holds that companies try to achieve a stable capital structure in the long term; thus, companies that, at a given time, are characterised by a relatively low (or high) level of debt, also probably had the same level in previous periods. Purpose of the article: The main purpose of this paper is to provide answers to two basic questions: 1) How did the aggregate capital structure of the non-financial companies listed on the Warsaw Stock Exchange
} 
(WSE) change from 1997 to 2017?; 2) What factors are decisive for the companies' capital structure and do the current trends in capital structure theory take account of them?

Research methods: The research is carried out in two phases. In phase 1, the descriptive statistics method is applied to analyse how the capital structure of WSE-listed companies changed in the years 1997-2017. In phase 2, the capital structure determinants are examined using multiple regression models.

Main findings: The capital structure of WSE companies varied significantly in the sample years, and overall, the debt ratios, total, short-, and long-term debt slightly increased. The causes of the changes were the economic environment factors (banking sector assets, government debt, and corporate income tax) and macroeconomic circumstances, along with the companies' characteristics. Among the latter, the company's profitability and the share of fixed assets in total assets usually turned out to be statistically significant.

\section{Introduction}

Shaping corporate capital structure is one of the most important and debatable issues for practitioners and the modern theory of corporate finance. Although it has inspired the creation of numerous theoretical approaches, a universally accepted theory of capital structure has yet to be developed. The existing capital structure theories form several groups, the best-known of which are referred to as the "tradeoff theory" and "pecking order theory". There are also a number of other theories, such as the "market timing theory", set in the framework of behavioural finance. The pecking order theory holds that it is not possible to determine the long-run optimal capital structure for a single company, although the rational order of raising funds for new investment projects can be decided. According to the trade-off approach, a company's capital structure represents a compromise primarily between the tax shield (increasing the company's market value along with increasing debt) and the associated bankruptcy and agency costs. The approach allows managers acting in a rational manner to determine the optimal capital structure for their company and to try to pursue it as a part of shaping the company's capital structure. Some empirical studies have shown that in highly developed countries such as the United States (US), the trade-off approach is used in practice, with many managers reporting that they attempt to determine the optimal or target debt ratio. However, in most cases, this is not defined as a strict debt ratio value, but rather as a somewhat tight target (Graham $\&$ Harvey, 2000) that managers try to maintain in the long run. Therefore, it is likely that companies which have a relatively low (high) level of debt at some point in time had the same level of debt in previous periods. This implies that scientists studying capital structure should be more focused on analysing and explaining its long-term composition rather than the short-term fluctuations and differences in the level of capital caused by temporary events.

The main purpose of this paper is to provide answers to two basic questions:

1. How did the aggregate capital structure of the non-financial companies listed on the Warsaw Stock Exchange (WSE) change from 1997 to 2017?

2. What factors are decisive for the companies' capital structure and do the current trends in the capital structure theory take account of them? 


\section{Long-term capital structure of enterprises - literature review}

The analysis of the long-term capital structure is not well-covered in the literature. The most important work in this field is the recently published "A Century of Capital Structure: The Leveraging of Corporate America", authored by Graham, Leary, and Roberts (2015), which provides an analysis of changes in the capital structure of US corporations in the last 100 years. The authors' findings show that the capital structure of the so-called unregulated companies was characterised by a steadily rising share of debt financing. This trend was common to companies of all sizes (small, large, and medium) and to entities operating in sectors defined by the Fama and French (2005) 12-industry classification. On the other hand, in the case of companies operating in the "regulated" sectors, their capital structure remained relatively stable over a long period of time. Graham, Leary, and Roberts concluded that the long-run stability of the aggregate debt ratio in US corporations was due to the different behaviour of companies in the regulated and unregulated sectors and to changes in the sectors' relative sizes (2015).

Some authors of capital structure studies reported that the share of debt in company financing is stable in the long term (Sametz, 1964; Wright, 2004; Frank \& Goyal, 2008) or showed a different degree of debt increase in the post-war period (Miller, 1977; Taggart, 1985; McDonald, 1983). Gordon and Malkiel (1981), Philippon (2012), Strebulaev and Yang (2013), and DeAngelo and Roll (2014) demonstrated that the debt level of US companies had increased in the second half of the $20^{\text {th }}$ century, while the proportion of organisations with relatively low debt had declined. Bates, Kahle, and Stulz (1982) and DeAngelo and Roll (2014), who used the $20^{\text {th }}$ century data to examine two samples of 50 and 24 companies, respectively, found that increasing debt was a kind of substitute for financing preferred shares. They also pointed to the high volatility of debt levels.

A distinctive characteristic of the above-mentioned studies of US companies is the use of long time series that sometimes span a century. As for Poland, the unavailability of a sufficiently long time series and the systemic changes that the Polish economy went through in the last century prevent conducting studies of similar time frames. The findings of such studies would also be of questionable value. This does not mean, however, that the importance of capital structure changes for Poland's economy has gone unnoticed by researchers. For instance, Łukasik and Nuczyński (2016) presented a study of changes in the capital structure of companies in Poland and some other European countries in the years 2007-2015, which also tried to determine which of the categories characterising the company have an impact on capital structure. Czerwonka (2017) examined the capital structure of Polish companies listed on the WSE in the period 1998-2013. At the micro-level, he primarily analysed which features of the companies, according to various capital structure theories, have an impact on the financing structure and a statistically significant impact on Polish economic conditions. Similar studies were carried out by Kubiak 
(2013), Chojnacka (2012), Wilimowska and Wilimowski (2010), Mazur (2007), Hamrol and Sieczko (2006), and Skowroński (2002), who analysed relationships between the characteristics of the sampled companies and their capital structure.

This paper examines the capital structure of WSE companies in the years 19972017 in terms of changes in their characteristics, but also taking account of the changes in the economic environment and macroeconomic data on Poland.

\section{Research sample}

The research sample comprised all the companies included in the Notoria Database which were listed on the WSE from 1997 to 2017. Two samples were separated from the mentioned time frame. The first consisted of 575 companies, whose shares were traded on the WSE for at least 12 months in the analysed period. The second sample had 21 companies that were listed on the WSE in all the analysed years. A similar number of organisations were used by DeAngelo and Roll in their study (2014). Financial firms were excluded from our analysis.

\section{Research method}

The research process was carried out in two phases. In the first phase, changes in the capital structure of WSE companies between 1997 and 2017 (annual data) were mainly analysed using descriptive statistics. In the second phase, multiple regression models were built to determine which of the factors indicated by various theories as influencing the capital structure had a statistically significant effect on the changes. Similar to the study by Graham, Leary, and Roberts (2015), the factors were divided into three categories.

The first category included factors describing the economic environment at large, i.e.:

a) corporate income tax,

b) the level of development of Poland's financial sector measured by the value of banking sector assets,

c) business risk measured by the volatility of GDP growth (standard deviation of the GDP growth rate over eight periods), and

d) government debt measured by the debt-to-GDP ratio.

Some capital structure theories indicate that the rate of the corporate income tax (CIT) has a bearing on the amount of benefits offered by debt financing. In the Miller-Modigliani model, a rise in the CIT rate encourages companies to increase debt ratios, as this is accompanied by an increase in the company's market value. The growth of the financial sector (measured by the value of banking sector assets) improves access to capital provided by banks, and thus, is primarily related to financ- 
ing with external capital. An increase in business risk due to the relationship with bankruptcy costs should reduce the share of debt financing. The rising government debt is also likely to reduce companies' financial leverage because the government and the economic sector compete for debt capital.

The second category consisted of macroeconomic factors, namely:

a) the real GDP growth rate,

b) the WIBOR $3 \mathrm{M}$ interest rate,

c) the rate of return on the stock market (WSE), and

d) the inflation rate.

The first of these factors is a general measure of the economic situation of the country, while the second and third are directly related to the cost of debt or equity capital. A relative increase in the cost of a given type of capital should reduce its share of financing. Although inflation is accounted for in several capital structure theories, its directional impact has not yet been clearly defined.

The last group of factors consisted of two micro-level indicators characterising the companies:

a) profitability - measured by the average EBIT/Assets ratio, and

b) the type of assets - measured by the ratio of fixed assets to total assets.

According to the pecking order theory, companies reduce debt financing as their profitability increases. Then, the theory of bankruptcy costs and the trade-off theory hold that an increase in fixed assets is likely to increase corporate debt, because fixed assets are more acceptable as collateral.

The regression analysis was performed on quarterly data from the period 1998:2 to 2017:4 (79 observations). The companies' data were sourced from the Notoria Database on the EMIS platform. The data on the economic environment and macroeconomic indicators were obtained from Poland's Central Statistical Office (GUS), Narodowy Bank Polski (NBP, the central bank) Eurostat, World Bank, and OECD.

\section{Results}

\section{Changes in the capital structure of Polish firms in the period 1997-2017}

The average values of debt/capital (equity) (D/C), long-term debt/capital (equity) (LD/C), and short-term debt/capital (equity) (SD/C) plotted in Figure 1 show how the capital structure of the selected non-financial firms changed in the sample years.

As Figure 1 shows, the changes were considerable. Consequently, the debt, measured by the level of ratios at the beginning and end of the analysed period, increased; however, substantial fluctuations could be observed throughout the period. The capital structure trends can be divided into four distinct periods. The first trend occurred in the years 1997-2001, when the share of debt financing increased. In the next period, 


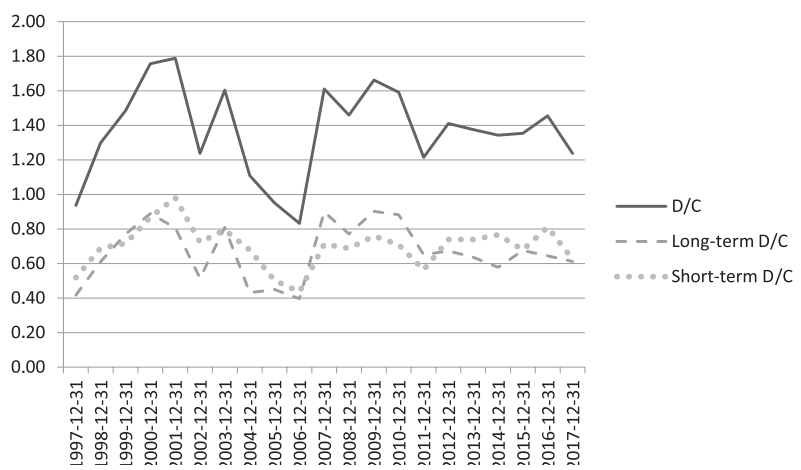

Figure 1. Capital structure changes according to the average values of $\mathrm{D} / \mathrm{C}, \mathrm{LD} / \mathrm{C}$, and $\mathrm{SD} / \mathrm{C}$ of WSElisted non-financial companies, years 1997-2017

Source: Authors' own study.

2001-2006, the share of debt financing declined, only to rise again in the years 20062010. In the fourth period spanning the years 2010-2017, the level of debt financing was relatively constant after falling in 2011. The highest debt/capital ratio occurred in 2001 (1.63) and the lowest (0.83) in 2006. It is notable that the trends followed by the long- and short-term debt/capital ratios were generally similar.

In interpreting the results above, it is important to remember that they were obtained for all companies that were listed on the WSE in the years of analysis, which causes some problems with data comparability because the numbers of companies included in the sample varied between years. Therefore, Figure 2 shows the average values of $\mathrm{D} / \mathrm{C}, \mathrm{LD} / \mathrm{C}$, and $\mathrm{SD} / \mathrm{C}$ for 21 firms that were listed on the WSE throughout the sample period of 1997 to 2017.

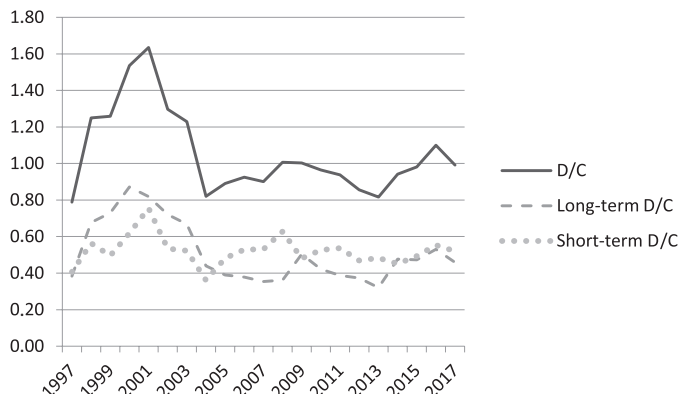

Figure 2. Capital structure according to the average values of D/C, LD/C, and SD/C of 21 WSE-listed nonfinancial companies in each year between 1997 and 2017

Source: Authors' own study.

In Figure 3, the $\mathrm{D} / \mathrm{C}$ ratios of the 21 firms are also shown as the median and the first and third quartiles. 


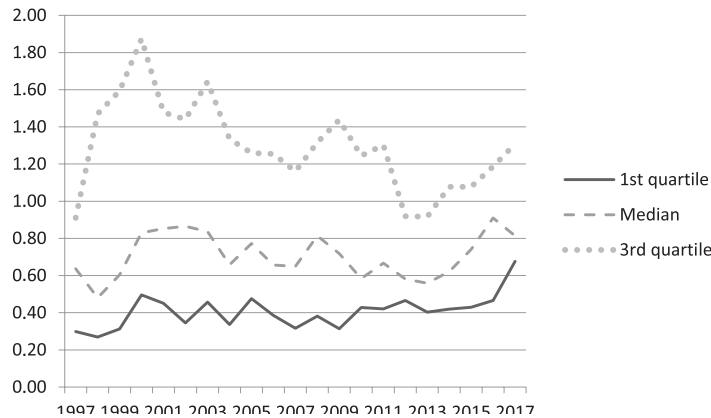

Figure 3. Capital structure changes according to the positional measures of the D/C ratio for 21 WSElisted non-financial companies in each year between 1997 and 2017

Source: Authors' own study.

Figures 1-3 reveal large fluctuations in the average values of the debt ratio, resulting in their values being higher at the end of the period. The fluctuations in the median of the $\mathrm{D} / \mathrm{C}$ were relatively smaller, but the value also increased by the end of the sample period.

In Figure 4, the capital structure for the average value of the $\mathrm{D} / \mathrm{C}$ ratio for companies divided into large, small, and medium-sized organisations according to the book value of their assets, is shown: small companies - assets in the first quartile, medium-sized - the second and third quartiles, and large companies - the fourth quartile.

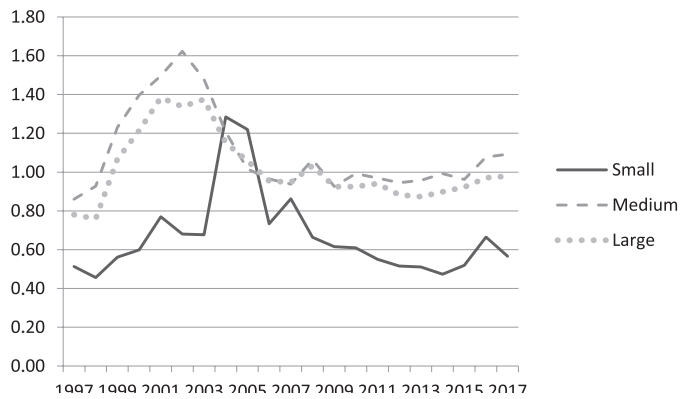

Figure 4. Average D/C ratios for small, medium, and large companies

Source: Authors' own study.

As can be seen in Figure 4, for almost all sample years, small companies had a lower level of debt than the medium and large ones that were similar. An exception was the years 2004 and 2005, when a higher $\mathrm{D} / \mathrm{C}$ ratio was noted for small companies.

The analysis also looked at companies divided into regulated and unregulated categories because of opinions that the more regulated companies may be forced to seek other methods of financing. A study on the US economy has shown that both 
types of organisations are fundamentally different regarding capital structure trends (e.g. Graham, Leary, and Roberts, 2015). In the Polish economy, the division of companies into regulated and unregulated was adopted per the report Ingerencja państwa $w$ wybranych sektorach gospodarki - skala $i$ warunki sukcesu (2018) by DNB Bank Polska. According to this report, the most regulated sectors are: pharmaceuticals, medicine, energy, and telecommunications. Figures 5 and 6 show the D/C, $\mathrm{LD} / \mathrm{C}$, and $\mathrm{SD} / \mathrm{C}$ ratios for the unregulated and regulated companies, respectively.

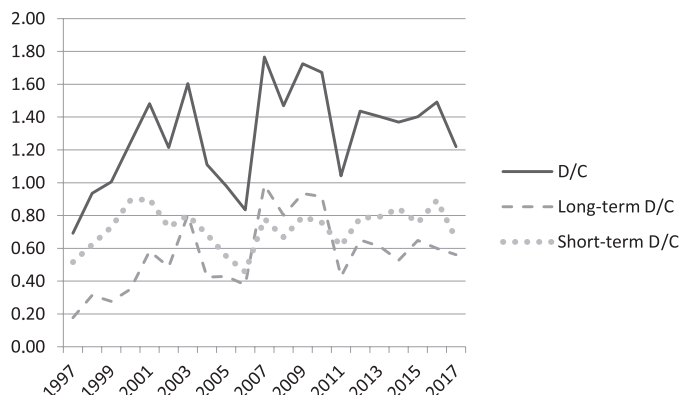

Figure 5. Average $\mathrm{D} / \mathrm{C}, \mathrm{LD} / \mathrm{C}$, and $\mathrm{SD} / \mathrm{C}$ ratios for the unregulated companies

Source: Authors' own study.

The values of all ratios calculated for the unregulated companies show considerable fluctuations between particular years; however, at the end of the period, they are only slightly than the baseline. For most of the analysed period, short-term debt financing dominated long-term debt financing; however, in the last year, the difference between them was not substantial.

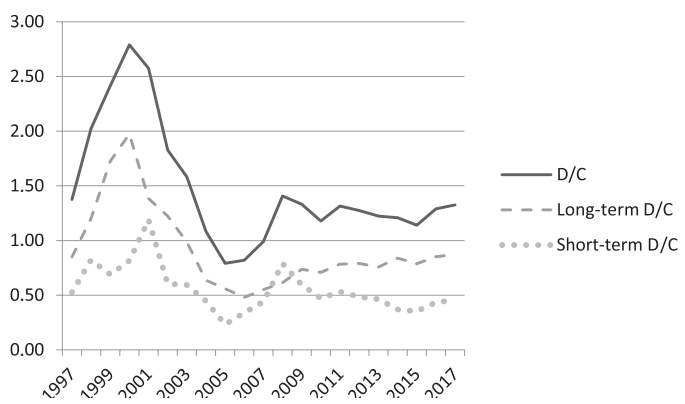

Figure 6. Average $\mathrm{D} / \mathrm{C}, \mathrm{LD} / \mathrm{C}$, and $\mathrm{SD} / \mathrm{C}$ ratios for the regulated companies (pharmaceuticals, medicine, energy, telecommunications)

Source: Authors' own study.

The capital structure of the regulated companies was similar to the capital structure of all other companies and did not significantly change after 2008 . The regulated companies' share of debt financing did not significantly change over the sample period, 
but its values in particular years were significantly different, with the highest values of the analysed ratios being recorded at the baseline and in the years 2000 and 2001. As for the regulated companies, long-term debt was larger than short-term debt in all years except 2008 .

The capital structure of companies representing different industries was also compared. The statement is often made that the factor differentiating the level of structure is the industry or sector of the economy, due to various determinants affecting this structure. If so, individual industries may show a steady preference for maintaining debt at a higher, lower or close to average level. The results of this research show that such a consistency of preferences is unique in the Polish economy. However, this allows the division of industries into those where the level of debt exceeded the average for most of the analysed period, and those where it was mostly lower. An example of the first group of industries is construction companies (see Figure 7) and examples of the second group are chemical and mining companies (see Figure 8 and 9 , respectively). Interestingly, in none of the cases are the debt trends consistent: in some years, the level of debt in the construction sector is lower than average, and there are years when the mining and chemical sectors' debt is higher than average.

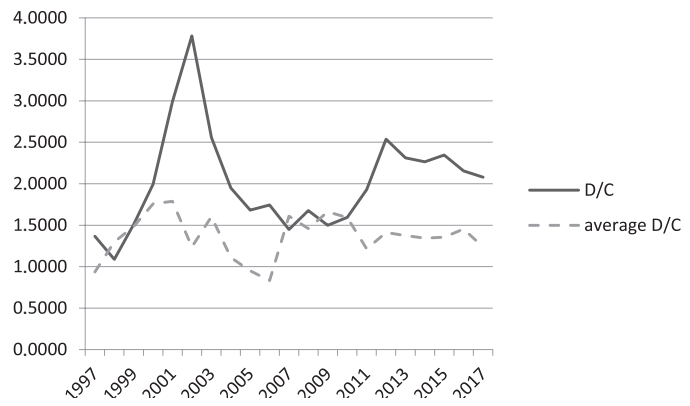

Figure 7. Average D/C ratio for construction sector companies Source: Authors' own study.

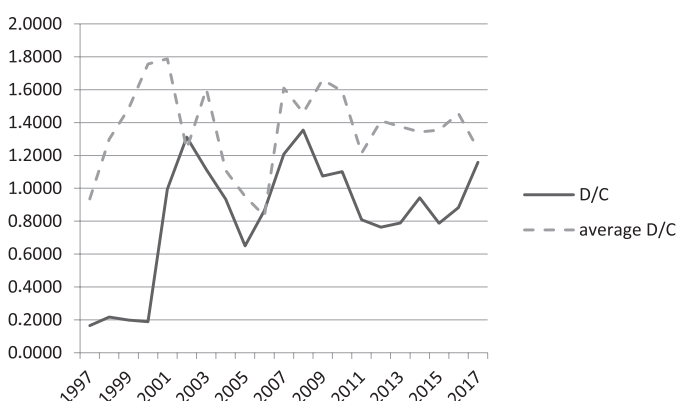

Figure 8. Average D/C ratio for chemical sector companies 


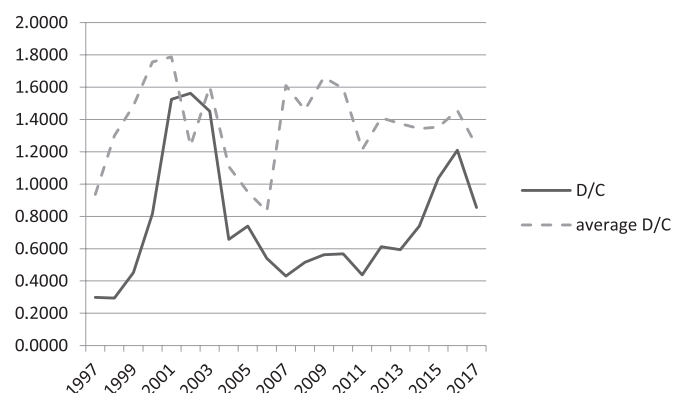

Figure 9. Average $\mathrm{D} / \mathrm{C}$ ratio for mining sector companies

Source: Authors' own study.

\section{Factors affecting the capital structure of companies}

As already mentioned, there are three groups of factors that can influence the capital structure of companies. These are: the economic environment factors, macroeconomic factors, and microeconomic factors.

Two regression models were constructed to capture relationships between the capital structure and the three groups of factors. Specifically, we estimated two regressions for the levels and changes in the capital structure as follows:

Model 1: D/C $\mathrm{C}_{\mathrm{t}}=\alpha_{\mathrm{i}}+\sum \beta_{\mathrm{i}} * \mathrm{E}_{\mathrm{t}}+\sum \gamma_{\mathrm{i}} * \mathrm{X}_{\mathrm{t}}+\sum_{2}^{4} \delta_{\mathrm{i}} * \mathrm{U}_{\mathrm{t}}+\varepsilon_{\mathrm{t}}$

Model 2: $\Delta \mathrm{D} / \mathrm{C}_{\mathrm{t}}=\alpha_{\mathrm{i}}+\sum \beta_{\mathrm{i}} * \Delta \mathrm{E}_{\mathrm{t}}+\sum \gamma_{\mathrm{i}} * \Delta \mathrm{X}_{\mathrm{t}}+\varepsilon_{\mathrm{t}}$

where:

$D / C_{t}$ - debt-to-capital ratio (total liabilities to capital [equity]) (sample average),

$E_{t}$ - the economic environment factors,

$X_{t}$ - macroeconomic and microeconomic (sample average) factors, and

$U_{t}$ - dummy variable taking a value of 1 for a given quarter.

We used $\Delta$ to denote the first-difference operator $\left(\Delta \mathrm{D} / \mathrm{C}_{\mathrm{t}}=\mathrm{D} / \mathrm{C}_{\mathrm{t}}-\mathrm{D} / \mathrm{C}_{\mathrm{t}-1}\right)$.

The regression analysis was performed on quarterly data spanning the period from 1998:2 to 2017:4 (79 observations). The models were estimated by the ordinary least squares (OLS) method. No collinearity was found among the independent variables because most VIF values were $<5$.

Table 1 presents the OLS regression results for model 1, which were estimated for 21 companies that were listed on the WSE in all sample years. 
Pobrane z czasopisma Annales H - Oeconomia http://oeconomia.annales.umcs.pl

Data: 26/04/2023 16:27:25

CHANGES IN THE CAPITAL STRUCTURE OF POLISH COMPANIES DURING THE LAST TWENTY YEARS..

Table 1. Linear regression coefficients for model 1 estimated for 21 non-financial companies listed on the WSE in each year between 1997 and 2017

\begin{tabular}{|c|c|c|c|c|c|}
\hline & \multicolumn{5}{|c|}{$\begin{array}{c}\text { Level regressions } \\
\text { Dependent variable: } \mathrm{D} / \mathrm{C}\end{array}$} \\
\hline & (1) & (2) & (3) & (4) & (5) \\
\hline \multirow[t]{2}{*}{ Constant } & $-0.484 *$ & 0.058 & -0.072 & -0.087 & $-0.644^{*}$ \\
\hline & 0.080 & 0.606 & 0.204 & 0.194 & 0.063 \\
\hline \multirow[t]{2}{*}{ Bank assets } & 0.024 & & & & $0.051 * *$ \\
\hline & 0.127 & & & & 0.013 \\
\hline \multirow[t]{2}{*}{ Government debt } & & -0.21 & & & $-0.518 * *$ \\
\hline & & 0.180 & & & 0.006 \\
\hline \multirow[t]{2}{*}{ GDP volatility } & & & -1.241 & & -1.423 \\
\hline & & & 0.312 & & 0.310 \\
\hline \multirow[t]{2}{*}{ Corporate income tax } & & & & 0.071 & 0.18 \\
\hline & & & & 0.683 & 0.347 \\
\hline \multirow[t]{2}{*}{ WIBOR 3M } & 0.264 & -0.145 & 0.1 & -0.035 & -0.054 \\
\hline & 0.169 & 0.427 & 0.465 & 0.871 & 0.818 \\
\hline \multirow[t]{2}{*}{ Inflation rate } & 1.046 & $1.564 *$ & 1.335 & $1.437 *$ & $1.452 *$ \\
\hline & 0.210 & 0.061 & 0.104 & 0.093 & 0.076 \\
\hline \multirow[t]{2}{*}{ WIG rate of return } & 0.018 & 0.002 & -0.007 & -0.002 & 0.007 \\
\hline & 0.654 & 0.963 & 0.863 & 0.956 & 0.854 \\
\hline \multirow[t]{2}{*}{ Real GDP growth } & -0.547 & -0.628 & -0.563 & -0.598 & $-0.655^{*}$ \\
\hline & 0.192 & 0.138 & 0.184 & 0.163 & 0.100 \\
\hline \multirow[t]{2}{*}{ Profitability } & -0.028 & -0.323 & -0.209 & -0.237 & 0.232 \\
\hline & 0.926 & 0.212 & 0.425 & 0.378 & 0.473 \\
\hline \multirow[t]{2}{*}{ Fixed assets } & $0.611 * * *$ & $0.549 * * *$ & $0.576^{* * *}$ & $0.57 * * *$ & $0.633 * * *$ \\
\hline & 0.000 & 0.000 & 0.000 & 0.000 & 0.000 \\
\hline \multirow[t]{2}{*}{ Quarter II } & 0.012 & 0.013 & 0.013 & 0.012 & 0.014 \\
\hline & 0.291 & 0.268 & 0.282 & 0.311 & 0.195 \\
\hline \multirow[t]{2}{*}{ Quarter III } & 0.019 & $0.027 *$ & 0.024 & 0.024 & 0.022 \\
\hline & 0.212 & 0.077 & 0.117 & 0.110 & 0.133 \\
\hline \multirow[t]{2}{*}{ Quarter IV } & 0.008 & 0.005 & 0.007 & 0.007 & 0.011 \\
\hline & 0.502 & 0.700 & 0.562 & 0.601 & 0.387 \\
\hline R-squared & 0.622 & 0.619 & 0.614 & 0.610 & 0.671 \\
\hline
\end{tabular}

Source: Authors' own study.

Note: $* * * * *$, and $*$ denote statistical significance at $1 \%, 5 \%$, and $10 \%$, respectively.

The estimation results showed that the following were statistically significant: the economic environment factors (banking sector assets and government debt), two macroeconomic factors (inflation and real GDP growth), and one micro-level factor (fixed assets).

Table 2 shows the parameters of model 2, which were estimated for 21 companies. The dependent variable in the model was annual changes in the $\mathrm{D} / \mathrm{C}$ ratio (quarter to the previous year's quarter) and the independent variables were annual changes in the factors' values (quarter to the previous year's quarter). 
Pobrane z czasopisma Annales H - Oeconomia http://oeconomia.annales.umcs.pl

Data: 26/04/2023 16:27:25

64

JERZY GAJDKA, MAREK SZYMAŃSKI

Table 2. Linear regression coefficients for model 2 estimated for 21 non-financial companies listed on the WSE in each year between 1997 and 2017

\begin{tabular}{|c|c|c|c|c|c|}
\hline & \multicolumn{5}{|c|}{$\begin{array}{l}\text { First-difference regressions } \\
\text { Dependent variable: } \Delta \mathrm{D} / \mathrm{C}\end{array}$} \\
\hline & (1) & (2) & (3) & (4) & (5) \\
\hline \multirow[t]{2}{*}{ Constant } & 0.001 & 0.001 & 0.001 & 0.001 & 0.001 \\
\hline & 0.808 & 0.823 & 0.790 & 0.789 & 0.728 \\
\hline \multirow[t]{2}{*}{ Bank assets } & -0.002 & & & & 0.003 \\
\hline & 0.610 & & & & 0.807 \\
\hline \multirow[t]{2}{*}{ Government debt } & & -0.081 & & & -0.224 \\
\hline & & 0.384 & & & 0.412 \\
\hline \multirow[t]{2}{*}{ GDP volatility } & & & 0.377 & & 0.596 \\
\hline & & & 0.849 & & 0.776 \\
\hline \multirow[t]{2}{*}{ Corporate income tax } & & & & 0.019 & 0.237 \\
\hline & & & & 0.932 & 0.561 \\
\hline \multirow[t]{2}{*}{ WIBOR 3M } & -0.146 & -0.182 & -0.16 & -0.145 & -0.297 \\
\hline & 0.690 & 0.620 & 0.671 & 0.692 & 0.454 \\
\hline \multirow[t]{2}{*}{ Inflation rate } & 0.651 & $0.683 *$ & 0.646 & 0.631 & $0.766^{*}$ \\
\hline & 0.111 & 0.096 & 0.119 & 0.121 & 0.076 \\
\hline \multirow[t]{2}{*}{ WIG rate of return } & 0.024 & 0.019 & 0.027 & 0.027 & 0.016 \\
\hline & 0.381 & 0.481 & 0.312 & 0.319 & 0.569 \\
\hline \multirow[t]{2}{*}{ Real GDP growth } & -0.257 & -0.263 & -0.259 & -0.257 & -0.275 \\
\hline & 0.284 & 0.271 & 0.281 & 0.284 & 0.258 \\
\hline \multirow[t]{2}{*}{ Profitability } & -0.058 & -0.019 & -0.108 & -0.109 & 0.005 \\
\hline & 0.734 & 0.915 & 0.457 & 0.469 & 0.977 \\
\hline \multirow[t]{2}{*}{ Fixed assets } & $0.531 * * *$ & $0.547 * * *$ & $0.501 * * *$ & $0.501 * * *$ & $0.527 * * *$ \\
\hline & 0.000 & 0.000 & 0.000 & 0.000 & 0.000 \\
\hline R-squared & 0.776 & 0.777 & 0.775 & 0.775 & 0.781 \\
\hline
\end{tabular}

Source: Authors' own study.

Note: $* * * * *$, and $*$ denote statistical significance at $1 \%, 5 \%$, and $10 \%$, respectively.

The first-difference regression showed that two variables were statistically significant: inflation and fixed assets.

The estimation results of model 1 for all 575 companies listed on the WSE for at least one year in the sample period are presented in Table 3. 
Pobrane z czasopisma Annales H - Oeconomia http://oeconomia.annales.umcs.pl

Data: 26/04/2023 16:27:25

CHANGES IN THE CAPITAL STRUCTURE OF POLISH COMPANIES DURING THE LAST TWENTY YEARS..

Table 3. Linear regression coefficients for model lestimated for all non-financial companies listed on the WSE in the period 1997-2017

\begin{tabular}{|c|c|c|c|c|c|}
\hline & \multicolumn{5}{|c|}{$\begin{array}{c}\text { Level regressions } \\
\text { Dependent variable: } \mathrm{D} / \mathrm{C}\end{array}$} \\
\hline & (1) & (2) & (3) & (4) & $(5)$ \\
\hline \multirow[t]{2}{*}{ Constant } & 0.424 & $1.384 * *$ & $1.149 * *$ & 0.674 & -1.114 \\
\hline & 0.800 & 0.056 & 0.004 & 0.151 & 0.614 \\
\hline \multirow[t]{2}{*}{ Bank assets } & 0.045 & & & & 0.153 \\
\hline & 0.685 & & & & 0.265 \\
\hline \multirow[t]{2}{*}{ Government debt } & & -0.549 & & & -1.029 \\
\hline & & 0.630 & & & 0.458 \\
\hline \multirow[t]{2}{*}{ GDP volatility } & & & -4.248 & & -1.053 \\
\hline & & & 0.643 & & 0.923 \\
\hline \multirow[t]{2}{*}{ Corporate income tax } & & & & 1.785 & 2.19 \\
\hline & & & & 0.171 & 0.145 \\
\hline \multirow[t]{2}{*}{ WIBOR 3M } & 1.247 & 0.29 & 1.021 & -0.917 & -0.685 \\
\hline & 0.360 & 0.827 & 0.272 & 0.534 & 0.699 \\
\hline \multirow[t]{2}{*}{ Inflation rate } & 2.877 & 4.307 & 3.434 & 5.735 & 5.222 \\
\hline & 0.603 & 0.432 & 0.514 & 0.292 & 0.359 \\
\hline \multirow[t]{2}{*}{ WIG rate of return } & -0.397 & -0.442 & -0.462 & $-0.581 * *$ & -0.506 \\
\hline & 0.180 & 0.116 & 0.108 & 0.050 & 0.109 \\
\hline \multirow[t]{2}{*}{ Real GDP growth } & -0.672 & -0.948 & -0.741 & -1.007 & -0.822 \\
\hline & 0.823 & 0.752 & 0.804 & 0.733 & 0.784 \\
\hline \multirow[t]{2}{*}{ Profitability } & $-0.578 * * *$ & $-0.621 * * *$ & $-0.588 * * *$ & $-0.526 * * *$ & $-0.438 * *$ \\
\hline & 0.001 & 0.000 & 0.000 & 0.002 & 0.023 \\
\hline \multirow[t]{2}{*}{ Fixed assets } & 0.359 & 0.41 & 0.345 & 0.574 & 0.494 \\
\hline & 0.494 & 0.427 & 0.513 & 0.276 & 0.372 \\
\hline \multirow[t]{2}{*}{ Quarter II } & -0.025 & -0.021 & -0.022 & -0.039 & -0.041 \\
\hline & 0.773 & 0.810 & 0.797 & 0.650 & 0.639 \\
\hline \multirow[t]{2}{*}{ Quarter III } & 0.058 & 0.087 & 0.067 & 0.074 & 0.043 \\
\hline & 0.624 & 0.446 & 0.546 & 0.500 & 0.715 \\
\hline \multirow[t]{2}{*}{ Quarter IV } & -0.024 & -0.022 & -0.019 & -0.026 & -0.037 \\
\hline & 0.781 & 0.791 & 0.822 & 0.758 & 0.667 \\
\hline R-squared & 0.325 & 0.325 & 0.325 & 0.342 & 0.356 \\
\hline
\end{tabular}

Source: Authors' own study.

Note: $* * * * *$, and $*$ denote statistical significance at $1 \%, 5 \%$, and $10 \%$, respectively.

In the case of a sample consisting of 575 companies, the rate of return on the WSE index and the company's profitability turned out to be statistically significant. It is noteworthy that the composition of the sample changed between years as companies were included in or excluded from the stock exchange listing.

The last table presents the values of the parameters of model 2 estimated for all 575 companies. 
Pobrane z czasopisma Annales H - Oeconomia http://oeconomia.annales.umcs.pl Data: 26/04/2023 16:27:25

Table 4. Linear regression coefficients for model 2 estimated for all non-financial companies listed on the WSE in the period 1997-2017

\begin{tabular}{|c|c|c|c|c|c|}
\hline & \multicolumn{5}{|c|}{$\begin{array}{l}\text { First-difference regressions } \\
\text { Dependent variable: } \Delta D / C\end{array}$} \\
\hline & $(1)$ & $(2)$ & (3) & (4) & (5) \\
\hline \multirow[t]{2}{*}{ Constant } & 0.002 & 0.002 & -0.006 & 0.013 & 0.009 \\
\hline & 0.962 & 0.948 & 0.874 & 0.695 & 0.785 \\
\hline \multirow[t]{2}{*}{ Bank assets } & $0.111 * * *$ & & & & 0.032 \\
\hline & 0.000 & & & & 0.782 \\
\hline \multirow[t]{2}{*}{ Government debt } & & $2.807 * * *$ & & & 1.098 \\
\hline & & 0.000 & & & 0.655 \\
\hline \multirow[t]{2}{*}{ GDP volatility } & & & 18.281 & & 9.374 \\
\hline & & & 0.336 & & 0.606 \\
\hline \multirow[t]{2}{*}{ Corporate income tax } & & & & $6.954 * * *$ & 3.148 \\
\hline & & & & 0.000 & 0.361 \\
\hline \multirow[t]{2}{*}{ WIBOR 3M } & -0.179 & 1.02 & -1.375 & -1.348 & -0.675 \\
\hline & 0.956 & 0.759 & 0.714 & 0.686 & 0.850 \\
\hline \multirow[t]{2}{*}{ Inflation rate } & 5.219 & 4.189 & 4.308 & 5.216 & 5.696 \\
\hline & 0.186 & 0.289 & 0.339 & 0.195 & 0.175 \\
\hline \multirow[t]{2}{*}{ WSE rate of return } & -0.268 & -0.196 & -0.429 & -0.347 & -0.233 \\
\hline & 0.270 & 0.433 & 0.110 & 0.158 & 0.368 \\
\hline \multirow[t]{2}{*}{ Real GDP growth } & 2.318 & 2.576 & 2.828 & 2.559 & 2.381 \\
\hline & 0.277 & 0.231 & 0.232 & 0.239 & 0.273 \\
\hline \multirow[t]{2}{*}{ Profitability } & $-0.338 * * *$ & $-0.35 * * *$ & $-0.229^{*}$ & $-0.305^{* *}$ & $-0.331 * *$ \\
\hline & 0.001 & 0.001 & 0.095 & 0.017 & 0.011 \\
\hline \multirow[t]{2}{*}{ Fixed assets } & $-0.832 *$ & -0.63 & 0.392 & -0.497 & -0.842 \\
\hline & 0.070 & 0.150 & 0.304 & 0.244 & 0.076 \\
\hline R-squared & 0.328 & 0.314 & 0.171 & 0.300 & 0.337 \\
\hline
\end{tabular}

Source: Authors' own study.

Note: $* * * * *$, and $*$ denote statistical significance at $1 \%, 5 \%$, and $10 \%$, respectively.

The estimates obtained for all companies pointed to the statistical significance of the economic environment factors (banking sector assets, government debt, and corporate tax), and of one microeconomic factor - the company's profitability.

In summary, only a few of the factors considered in the study proved statistically significant in influencing the level or changes in the debt ratios of companies. It is interesting, however, that they represented all groups' factors. In the case of the sample containing all non-financial companies, both models indicated that profitability was statistically significant. This seems to imply that both the level and changes in the capital structure are best explained by the pecking order theory, which holds that the primary source of financing for companies is their internal resources. This means that high profits allow them to reduce the debt level. The statistical significance of other variables was less obvious. However, two findings are certainly worth noting. First, the coefficient for income tax (rate) was positive, which is consistent with capital structure theory, such as the Miller-Modigliani theory (companies increase debt as the income 
tax rate goes up). Second, the coefficient for government debt was negative, meaning that the companies' debt was increasing with government debt. Therefore, a state lender does not significantly "crowd out" firms from the debt market as is often claimed.

The regression results obtained for the 21 companies that had been listed on the WSE throughout the sample period showed that in both models, the fixed assets (the share of fixed assets in total assets) were the most statistically significant. The positive coefficient for the fixed assets indicates compliance with the bankruptcy costs theory and the trade-off theory. This means that an increase in fixed assets which are usually welcome as a collateral for a debt results in a larger debt share of capital structure. As for the other variables, the research results show that increasing government debt and GDP growth are associated with a fall in the companies' debt, whereas increasing assets of the banking sector and rising inflation reduce the share of debt financing, which largely aligns with theoretical expectations.

In neither of the analysed models was the interest rate (WIBOR 3M) statistically significant, which seems surprising from the point of view of financial theory.

\section{Conclusions}

This paper presented the results of a study of changes in the capital structure of companies listed on the WSE in the years from 1997 to 2017. As the results indicate, the capital structure of companies changed in the sample period and the debt ratios, total, short- and long-term, slightly increased. The trend was observed among companies regardless of their size (small, medium-sized, and large). The small companies had the smallest share of debt financing in all the years of analysis.

The analysis of factors determining the capital structure of companies showed the influence of factors related to the economic environment, along with the macroeconomic and microeconomic factors. In most cases, the company's profitability and the share of fixed assets in total assets were statistically significant. The signs of all coefficients indicated that the results were consistent with the pecking order theory, the bankruptcy costs theory, and the trade-off theory. It can be concluded that on the basis of these theories, the explanation of changes in the capital structure of Polish companies should be sought in the last 20 years, although a more accurate explanation of these changes requires further research.

\section{References}

Bates, T., Kahle, K., \& Stulz, R. (1982). Why do U.S. firms hold so much more cash than they used to? The Journal of Finance, 64(5), 2085-2121.

Chojnacka, E. (2012). Struktura kapitatu polskich spótek akcyjnych w świetle teorii hierarchii źródet finansowania. Warszawa: CeDeWu. 
Czerwonka, L. (2017). Struktura kapitału polskich spółek w świetle wybranych teorii struktury kapitału. Wspótczesna Gospodarka, 8(1), 51-63.

DeAngelo, H., \& Roll, R. (2015). How stable are corporate capital structures? The Journal of Finance, 70(1), 373-418. doi:10.1111/jofi.12163

Fama, E., \& French, K. (2005). Financing decisions: Who issues stock? Journal of Financial Economics, 76(3), 549-582. doi:10.1016/j.jfineco.2004.10.003

Frank, M., \& Goyal, V. (2008). Tradeoff and pecking order theories of debt. In: E. Eckbo (Ed.), Handbook of Corporate Finance. Empirical Corporate Finance (pp. 135-202), Vol. 2. North-Holland: Elsevier.

Gordon, R., \& Malkiel, B. (1981). Corporate finance. In: H. Aaron, J. Pechman (Eds.), How Taxes Affect Economic Behavior (pp. 131-192). Washington D.C.: The Brookings Institution.

Graham, J., \& Harvey, C. (2000). The theory and practice of corporate finance: Evidence from the field. Journal of Financial Economics, 60(2-3), 187-243. doi:10.1016/S0304-405X(01)00044-7

Graham, J., Leary, M., \& Roberts, M. (2015). A century of capital structure: The leveraging of corporate America. Journal of Financial Economics, 118(3), 658-683. doi:10.1016/j.jfineco.2014.08.005

Hamrol, M., \& Sieczko, J. (2006). Czynniki kształtujące strukturę kapitału polskich spółek giełdowych. Prace i Materiały Wydziału Zarzadzania Uniwersytetu Gdańskiego, (1), 127-141.

Ingerencja państwa w wybranych sektorach gospodarki - skala i warunki sukcesu. (2018). DNB Bank Polska. Retrieved from https://www.dnb.pl/pl/kierunki/kierunki2018

Kubiak, J. (2013). Zjawisko asymetrii informacji a struktura kapitatu przedsiębiorstw w Polsce. Poznań: Wydawnictwo Uniwersytetu Ekonomicznego.

Łukasik, G., \& Nurzyński, D. (2016). Relacje kapitałowe w Polsce i w wybranych krajach europejskich. Studia Ekonomiczne Zeszyty Naukowe Uniwersytetu Ekonomicznego w Katowicach, (282), 80-93.

Mazur, K. (2007). Determinanty struktury kapitału polskich przedsiębiorstw. Ekonomika i Organizacja Przedsiębiorstwa, (8), 21-27.

McDonald, R. (1983). Government debt and private leverage: An extension of the Miller theorem. Journal of Public Economics, 22, 303-325. doi:10.3386/w0965

Miller, M. (1977). Debt and taxes. TheJournal of Finance, 32(2), 261-275. doi:10.1111/j.1540-6261.1977.tb03267.x

Philippon, T. (2012). Has the US finance industry became less efficient? On the Theory and Measurement of Financial Intermediation. Unpublished working paper. New York University.

Sametz, A. (1964). Trends in the volume and composition of equity finance. The Journal of Finance, 19(3), 450-469. doi:j.1540-6261.1964.tb02867.x

Skowroński, A. (2002). Czynniki kształtujące strukturę kapitału polskich przedsiębiorstw w świetle badań empirycznych. In: J. Sobiech (red.), Kapitałowa strategia przedsiębiorstwa (pp. 59-73). Poznań: Wydawnictwo Naukowe Uniwersytetu Poznańskiego.

Strebulaev, I., \& Yang, B. (2013). The mystery of zero-leverage firms. Journal of Financial Economics, 109(1), 1-23. doi:10.1016/j.jfineco.2013.02.001

Taggart, R. (1985). Secular patterns in the financing of U.S. corporations. In: B.M. Friedman (Ed.), Corporate Capital Structures in the United States (pp. 13-18). Chicago: University of Chicago Press.

Wilimowska, Z., \& Wilimowski, M. (2018). Wpływ czynników mikroekonomicznych na zarządzanie strukturą kapitałową polskich przedsiębiorstw. In: Z. Knosala (red.), Komputerowe zintegrowane zarządzanie (pp. 627-641). Opole: Oficyna Wydawnicza Polskiego Towarzystwa Zarządzania Produkcją.

Wright, S. (2004). Measures of stock market value and returns for the US non-financial corporate sector, 1900-2002. The Review of Income and Wealth, 50(4), 561-584. doi:10.1111/j.0034-6586.2004.00140.x 